\title{
BUILDING PARTNERSHIP ACROSS RURAL TOURISM DESTINATION FOR SUSTAINABILITY: A CASE STUDY IN SPECIAL REGION OF YOGYAKARTA, SOME CHALLENGES AND OPPORTUNITIES
}

\author{
Aris Chandra Pradikta. \\ Universitas Gadjah Mada \\ chandraaris@gmail.com
}

\begin{abstract}
Tourism destination in rural areas often face difficulties to sustain its competitiveness dimension. Economic-geography approach extent the discussion of tourism development that integrate spatial and economic as a result of evolutionary pattern on tourism activities in rural areas. However, within proliferation background of rural tourism destinations such as Special Region of Yogyakarta, 112 rural tourism destinations in a region, are considered as highly competitive and threaten of the future rural tourism destinations sustainability. Therefore, moving beyond focus within a single destination is necessary in order to gain new perspective and reconstruct the regional policy development. This paper tries to reveal some challenges and opportunities in building partnerships across rural tourism destinations. Data in this paper is complemented by graduate thesis research and regional survey of rural tourism social mapping in Special Region of Yogyakarta that authors involved in. Research findings indicated that variables such as homogeneity of attractions, similarity of market sharing, and organizational capacity building are among major needed to address. In addition, top-down planning of local government is expected as a breakthrough of current conditions.
\end{abstract}

Keywords: rural tourism partnership, organizational network

\section{Introduction}

Economic-geography approach extent the discussion of tourism development that integrate spatial and economic as a result of evolutionary pattern on tourism activities in rural areas (Randinelli \& Tortorra, 2014; Ma \& Hassink, 2013). The presence of collaborative concepts, in addition, make rural tourism no longer can be deemed as a single-unit focus for its success building (Fotiadis et. al., 2016). Small business scale, which located in rural areas, interacts across border for learning process (Weidenfield, 2013). While Integrating such conditions can also be identified by the influence of network within tourism industries (Arnaboldi \& Spliller, 2011). Those are enabling interactions between actors and their resources, such as knowledge, culture and experience, to exchange information among others (Saxena \& Ilbery, 2007).

As one of the major destinations in Indonesia's tourism industry, Special 
Region of Yogyakarta, let alone in 2015, were making contributions approximately 4 million visitors [1] with average length of stays at 2,1 days [2]. In addition, from 2011 to 2015 , annual average of tourists' growth is about 6,22 percent [3]. The effects of vast tourism destination, perhaps have already given contributions to the development of rural tourism activities in Yogyakarta as well. While in 2008, there were only 30 destinations registered, until late 2014 their number reached 112 destinations [4]. Studies about rural tourism impact as supporting area and emerging new mass destinations become fashioned (de Almeida, 2010) as well as their shortcomings (Biddulph, 2015).

In spite of the large number and proliferation of rural tourism spots in Yogyakarta, there also remain some challenges. Based on provincial government studies, in term of indexing and measuring destinations, there are only $23 \%$ can be regarded as independent organizations (self-sufficient in term of organization funding, managing as well as marketing) [5]. Existing paradoxes, between increasing number of rural tourism destinations, increasing number of visitors and low number of active events in majority rural destinations, as well as stagnant number on length of stays for several years, are needed innovations to breakthrough current conditions.

In order to broadening conceptual of managing rural tourism and bring alternative point of views, current researches also have widely shown the significant contributions to make partnerships across destinations as a way of increasing tourism flow (Hong et.al, 2015). Among of them are using integration of marketing (Reid et. al, 2006), cluster learning (McLennan et.al., 2016) as well as event-based (Panyik et.al, 2011), as one of the models to enhance local destination's attractiveness. Those potential opportunities, however, are rarely be used as analytical concepts to develop rural tourism activities in Indonesia. Therefore, in results, such conditions often face uncoordinated market, competition and self-determinant profit making (Pradikta, 2016). While, on the other hand, current trends of tourism industry, prevail not only in competition but also need for cooperation between actors (Mariani, 2016).

This paper tries to investigates such issues in order to gain better understanding of how local actors respond prevailing proliferation trends in rural tourism activities, and to what extent do they willing to cooperate or to use noncooperative approach with other destinations. In addition, government efforts in connecting among destinations are also presented. Those are to evaluate current conditions and develop new policy for the future.

\section{Literature Review \\ 1.1 Rural tourism activities in Special Region of Yogyakarta}

Rural tourism in Special Region of Yogyakarta can possibly be traced from the very first idea of its development. As a response on economic crisis in 1998, three years later local leader had initiated to integrate activities such as farming and local livelihoods as a basis of leisure activities that boosted local economy (Asyari, 2015). After had gained promising results, some other local leaders also started running similar businesses in their own area. Until 2008 there were 30 rural and sub-urban tourisms (kampong wisata), or can be regarded as community based tourism related, operated within the region. 
In 2014, their numbers reached 112 destinations. Those destinations offer various attractions range from cultural, farming, education, local-based product to naturebased attractions. Where the area which possess the largest number, with 38 destinations, is Sleman regency (kabupaten) among other 3 regencies and a city in the province [6].

Based on social mapping survey, that author involved in, most of the 38 destinations which randomly chosen, use central management as form of managing and marketing of their attractions. Central management operates as coordinator among local businesses while central information for visitor that wanted to enjoy their vacation. When author once came to visit at several destinations, all of them are weighing the role of manager of central management to access related information. In addition, several businesses, either homestay, food catering, or farming-related tourism activities will work if there is an order from the manager. In political contexts, central manager also has role as representative of each destination if communicating with government or other parties-include private sector or nongovernment organizations (NGOs)-is necessary.

\subsection{Partnerships across destinations}

Partnerships differ in situations and contexts. In term of governance and inter-organizational relations, partnerships prevail formally or informally that requires two parties or more and across actors; such as government, private sector as well as civic and non-profit organizations (McQuaid, 2010). In business realm, partnership can be regarded as a way to sustain its organization's competitive advantage (Jiang, 2014). While competitive advantage is necessary for management to sustain in intense competition and globalization world (Barney, 2007).

Likewise, tourism industry has more extensive theoretical partnerships that already been compiled, it stresses on several factors for destination collaboration (Fyall et. al., 2012). Several important concepts among of them, connect current forming partnership theories and the mediating parties. In which, to what extents are complexities of each phases and within different background of theories. The partnerships building that identified in Special Region of Yogyakarta, stressed on network-based that occasionally mediated by government and the involvement of central local destination management. Several forms of partnerships exist informally as a response to short term interest of tourism practices.

Partnerships across destinations have several goals that based on local actor interests, in some extents they do sacrifice on immediate cost for longer benefits. Partnerships that destination marketing-intended for instance, are based on local consciousness that small business scale often faced in difficulties compared to larger competitors. Even though, integrating such rule of game with other parties are found not easily. While, on the other hand, competition will also lead to the divergent of market and split up resources. Thus, within term of partnership and collaboration, local destinations have chances to enhance their own branding along with similar or related supporting business.

Event-based also widely known as an instrument to build partnership. Sport activities, festivals, and MICE (meeting, incentive, convention and 
exhibition) are those among familiar events that often requires two parties or more that situated in some places (Wasche, 2015). Mega-sport event not only took place on urban area, but also rural as well. Thus, local business preparedness for accommodation, food and hospitality are relied among parties. Since benefits not only occur at a time but also having potential repeated visiting.

\subsection{Making decision for partnering across destinations}

Making decision in multi-stakeholder involvement is somehow complex as it is to make sure that every parties gain what are they wanted and match with own interests. Referring to staging and sequential by multi-stakeholder involvement management, at the first place, attracting stake holder is the first level before continue to integration and management phase (Waligo et.al, 2013). The framework offers conceptualization in well-constructed of multi-stake holders complexities.

In a setting of network where interactions are located and actors are communicating, making relations with outside community is necessarily supported by equal perceptions. Since perception as a basis of how actors perceive and being motivated, thus, spreading knowledge is needed. On the level of attractions, knowing stake holder's capacity and eligibility, are important. In this phase, differing include: goals, philosophy, powers, are among identified failure to step on the next levels (McQuaid, 2010).

After organization passes the attraction level, both parties start to negotiate and consolidate opportunities for partnering. Achievable objectives and more detail plans are now flooring to make common agreement and split responsibility. In addition, the involvement of mediated and supporting parties, such as government are needed to take in a place for advocating partnerships. Since government has particular power to influence actors, such as budget, authority or be the trusted party. Therefore, supportive policy is expected work as advocating in actors' shortcomings.

\section{Methodology}

This presenting research was undertaken in two sequences. First, the author's involvement, in social mapping survey of rural tourism in Special Region of Yogyakarta, allowed to gain access on descriptive-quantitative data of partnerships-related questions from the survey. The data of survey were collected from 38 destinations out of 112. Respondents were chosen based on stratified random sampling, that using 30\% basis from populations by location in each 4 municipals and 1 city, within the province. Respondents are leader or local manager of destinations. Since they know local businesses and visitors' conditions. Therefore, using purposive sampling of respondents, is deemed as effective way to gather information.

After the survey had conducted, deeper information was carried out based on qualitative study. Where the informants are mainly located in the north side of Sleman Regency. Several main reasons are provincial government's strategic planning that include those region as regional collaboration focus. In addition, Sleman Regency has the largest number of rural tourism destinations. In this qualitative study, prominence informants were chosen are local governments, 
local businesses, and local destination managers. Amount number of those informants are ten persons.

Data, that analysed and combined between survey results and qualitative study, are treated as complementary which expected for having better information in partnerships across destinations. The descriptive model for presenting data is based on multi-management framework (Waligo et.al, 2013). Which later, are improved by opportunities and challenges information for each levels.

\section{Results}

\subsection{Partnerships across rural tourism}

Based on primary survey data, it can be presented that $76 \%$ from 38 respondents in the province, have ever made partnerships agreement with other destinations. Majority answers is $45 \%$ using join trip as a basis for their partnerships model. While the involvement of travel agent takes into consideration as a mediated party for combining several different trip into single order. For travel agent's perspective, offering various distinct attractions is preferred, since rural areas often only possesses few prominent attractions. While, on the other hand, tourists are often eager if they can gain a lot of experiences during their vacation.

Education-tourism theme for instance, is offered by local travel agent that involving several attractions such as learn how to cultivate snake fruit crop, recycle waste, and conserve in forest area. Where, those are located in different rural tourism destinations such as Ledok Nongko, Sukunan and Kalibiru. Similar pattern is also found on Canada tourism area, that integrating marketing through alliances. In results, better customer handling achieves on increasing inbound tourists (Reid et. al, 2008).

Within Sleman Regency, partnerships occur mostly in form of transferring resources and visitors. Those are answered by 11 destinations of 13 surveyed local destination manager. Transfer resources exist when available demand can't be fulfilled with own resources. Thus, borrowing other destination attraction is common among local manager. The rationale reasons are close location and good relation ties among actors. In term of transferring visitors, it usually happens in peak season, while number of beds in one destination are not enough. In addition, suggesting visitors to change destination with similar attractions is mechanism that often undertaken by local manager to not disappointed their customers and not just let them off with empty hand.

Closeness tie of networks is necessary in order to maintain such relations among destination managers. Building trust with different actors is long process that requires effort. Fortunately, having mutual trust and understanding seems common between local actors. It can be understood from social capital dimension. Concepts such as willingness to cooperate, norm, trust and network, work as part of social capital that support rural development, particularly in tourism industry (Park et.al., 2012).

\subsection{Challenges to initiate and maintain partnerships}

Within the local manager's understanding, partnerships with different 
actors is regarded as necessary. Since they do know how their organization is not living in an isolated environment. However, building partnerships with another tourism village takes many considerations. Most prominent answer by local manager uses capacity of the destination as a push factor to achieve their goals. For instance, a destination that just enter tourism industry, would likely make contact with well-established destination and have better experiences.

"Before I had started running this business, I often made contact with founder of Tanjung village. In which, they were the first initiating rural tourism activities. I learnt a lot of things from them. How to manage, create new attraction, set prices, as well as communicate with people around us." Pentingsari Tourism Comitee-"

On the contrary, destination that regard having lack of capacity, try to avoid partnerships as a basis of their development. Rather, they would improve internal factor before stepping into partnership agreement with another destination.

"We village have a unique landscape, our attraction focused on different markets, therefore, we have a lot of chances if started to partner with our next door. For sure, making collaboration and integrating attraction will make our market better. But, before everything happens, we need to reform internal structure." -Sambi Tourism Comitee-

Those challenges of local destinations in building partnerships faced different organizational capacity environment. Where Tanjung village and Pentingsari made contact in between to improve organizational capacity. This is also supported by information that make partnerships is used to build capacity and learning process among actors (Mohamad et. al., 2013). While between Pentingsari and Sambi, one party tend to formulate its own management before extent to partnerships level.

In addition, even though the partnership-form based are common among actors, in opposition, perception sometimes become obstacles (Hashimoto \& Telfer, 2010). Perception is related to how local acceptance of outsider in building partnerships. Occasionally, local manager tends to see how running tourism industry as a competition-based. Thus, partnerships are the least chances of their management style.

On the integration level, while between parties pass organizational capacity's check point, intense communication and build relations enabling them to make sure how plan is carried out. Coordination is important to minimized unintended consequences during the execution. Event-based venue such "NgaYogjazz" for instance, is a jazz music event which taken place in rural areas. Where the main concept is bringing "high-end" market into "lower" image of rural areas.

Some regions are often involved in conducting the event. Therefore, it is necessary to make coordination among parties. Such private-initiative event needs local people and local district government for coordination. NgaYogjazz can be said as a success event for people with more than a thousand visitors during the event. Some main success factors lay on the carefully prepared in which area is ready to held. Similar results show how stakeholder capacity as a main contribution (Panyik et. al., 2011).

Management level of partnerships are the highest among integration and 
initiate level. It concerns about influencing capacity and monitoring its process. In the context of Special Region of Yogyakarta, so far this research take note, partnerships in this level are mostly government initiated. Since partnership across actors often occur only in the implementation level or short term interests. Those condition are caused by homogeneity of products and similar targeting market. Therefore, between actors tend to use competition as basis of development.

Local government influences on management of partnerships happened on the basis of regional communication. Forum Komunikasi Desa Wisata (rural tourism communication forum) is one of the forms that local actors can deliver their opinion, influence policy and structure common problem in order to find solutions. In this communication forum, local manager also be given information from local government.

\subsection{Opportunities and discussion}

Information that revealed in previous section describes shortcomings of local actors related-partnership. The main point shows that partnership among actors are often lack of strategic planning and low organizational capacity. In addition, homogeneity of market and products also take into consideration. Thus, there is needed to strengthen through macro planning by official.

Government intervention can address local capacity building improvement and introduce market awareness. In addition, top-down planning is needed in order to foster the development beyond a single unit interest. From the government perspective, often it is found not easy. Because rural tourism activity sometimes is regarded as market mechanism. It means reward is given to whomever could follow market demand. Similar result has also been found in South Korea's rural tourism activities. Particular policy could increase the nonfarming income of villagers. In addition, the uncertainty of condition lead to termination of program. Therefore, it did affect negatively on local livelihood in term of tourism activities. (Hwang \& Lee, 2015).

Current condition of using network as a way of managing actors can be improved through exploring the network governance concepts. More extensive and broad within network governance literature, such as perception management, network instruments, and network strategy, are possibly explored for future research. As it shifts of focus that involve various actors.

\section{Conclusion}

This paper provides basic research of partnerships across destination in Indonesia, which occur inside the frame or condition of Special Region of Yogyakarta. On the one hand, research results show that partnerships were used by majorities of local destination as model to run their businesses. On the other hand, very often partnerships occur only within immediate interest. Partnerships hardly ever made in strategic planning, that involves two parties or more and intended to influence long term organizational performances. Local actors still struggle with focusing on their own destination as a determinant of their success factors. Government intervention is expected to introduce partnerships concepts more intense and work as an advocate of individual rational choice and 
communal value of tourism activities in rural areas.

\section{Acknowledgement}

Research data in this paper is partially funded by Universitas Gadjah Mada through partnering with Prof. Muhadjir Darwin, M. PA and Dr. Setiadi, particularly in social mapping survey of rural tourism in Special Region of Yogyakarta. This research results are also part of graduate thesis of the author.

[1] Central Statistical Institute (Badan Pusat Statistik)

[2] Central Statistical Institute (Badan Pusat Statistik), Room occupancy rate Daerah Istimewa Yogyakarta, 2015

[3] Ibid.

[4] Evaluasi diri Dinas Pariwisata Provinsi DIY

[5] Ibid.

[6] Ibid.

\section{REFERENCES}

de Almeida, António Manuel Martins, 2010, From island mass tourism to rural tourism In Madeira: Is there a place for a re-definition of islands' image?, Polytechnical Studies Review, 3 (14), 97-110, ISSN: 1645-9911

Arnaboldi, Michela \& Spiller, Nicola, 2011, Actor-network theory and stakeholder collaboration: The case of Cultural Districts, Tourism Management, 32 (2011), 641-654, doi:10.1016/j.tourman.2010.05.016

Asyari, Hasbullah, 2015, Buku Pegangan Desa Wisata: Materi Bimbingan Teknis untuk Desa Wisata, Yogyakarta: Zeedny

Barney, Jay. B., dan Clark, Delwyn. N., 2007, Resource-Based Theory Creating and Sustaining Competitive Advantage, New York: Oxford University Press

Biddulph, Robin, 2015, Limits to mass tourism's effects in rural peripheries, Annals of Tourism Research, 50 (2015), 98-112, doi:10.1016/j.annals.2014.11.011

Fotiadis, Anestis, Yeh, Shih-Shuo \& Huan, Tzung-Cheng, T. C., 2016, Applying configural analysis to explaining rural-tourism success recipes, Journal of Business Research, 69 (4), 1479-1483, doi:10.1016/j.jbusres.2015.10.128

Fyall, Alan, Garrod, Brian, \& Wang, Youcheng, 2012, Destination collaboration:Acriticalreviewoftheoreticalapproaches to amultidimensionalphenomenon, Journal ofDestination Marketing \& Management, 1(2012), 10-26, dx.doi.org/10.1016/j.jdmm.2012.10.002

Hashimoto, Atsuko \& Telfer, David, J., 2010, Developing sustainable 
partnerships in rural tourism: the case of Oita, Japan, Journal of Policy Research in Tourism, Leisure \& Events, 2 (2), 165-183, DOI: 10.1080/19407963.2010.482276

Hong, Tao., Ma, Tao. \& Huan, Tzung-Cheng, 2015, Network Behaviour as Driving Forces as Tourism Flows, Journal of Bussiness Research, 68 (2015), 146-156, doi:10.1016/j.jbusres.2014.04.006

Hwang, JaeHee \& Lee, SeongWoo, 2015, The effect of the rural tourism policy on non-farm income in South Korea, Tourism Management, 46 (2015), 501-513, http://dx.doi.org/10.1016/j.tourman.2014.07.018

Jiang, Wei, 2014, Bussiness Partnership and Organizational Performance: The Role of Resources and Capabilities, Berlin: Springer-Verlag

Ma, Mulan \& Hassink, Robert, 2013, An Evolutionary Perspective on Tourism Area Development, Annals of Tourism Research, 41 (2013), 89-109, doi:10.1016/j.annals.2012.12.004

Mariani, Marcello, M., Coordination in inter-network co-opetitition: Evidence from the tourism sector, Industrial Marketing Management, 53 (2016), 103-123, dx.doi.org/10.1016/j.indmarman.2015.11.015

McLennan, Char-lee, J., Becken, Susanne., dan Watt, Melinda., 2016, Learning Through a Cluster Approach: Lessons from the Implementation of Six Australian Tourism Business Sustainability Programs, Journal of Cleaner Production, 111, 348-357, doi:10.1016/j.jclepro.2015.01.085

McQuaid, R.W.,2010, “The Theory of Partnerships - Why Have Partnerships”, Inside: S.P. Osborne (ed.), Managing public-private partnerships for public services: an international perspective (Routledge, London) p 9-35.

Mohamad, Nor, Haniza., Kesavan, Prasanna., Razzaq, Abdul, R. A., Hamza, Amran, Khalifah, Zainab, 2013, Capacity building: Enabling learning in rural community through partnership, Procedia - Social and Behavioral Sciences, 93 (2013), 1845 - 1849, doi: 10.1016/j.sbspro.2013.10.128

Panyik, Emese, Costa, Carlos dan Ratz, Tamara., 2011, Implementing Integrated Rural Tourism: An Event-Based Approach, Tourism Management, 32 (2011), 1352-1363, doi:10.1016/j.tourman.2011.01.009

Park, Duk-Byeong,. Lee, Kwang-Woo,. Choi, Hyun-Suk,. \& Yoon, Yooshik, 2012, Factors influencing social capital in rural tourism communities in South Korea, Tourism Management, 33 (2012), 1511-1520, doi: 10.1016/j.tourman.2012.02.005

Pradikta, Aris. C., 2016, Tantangan Pengembangan Kerja Sama Antar Desa Wisata: Studi Kasus Desa-Desa Wisata di Kawasan Cangkringan, 
Graduate Thesis: Universitas Gadjah Mada.

Randelli, Filippo, Romei, P. \& Tortora, M, 2014, An Evolutionary Approach to the Study of Rural Tourism, Land Use Policy Journal, 38 (2014), 276-281, doi:10.1016/j.landusepol.2013.11.009

Reid, Laurel, J., Smith, Stephen, L. J., \& McCloskey, Rob, 2008, The effectiveness of regional marketing alliances: A case study of the Atlantic Canada Tourism Partnership 2000-2006, Tourism Management, 29 (2008), 581-593, doi:10.1016/j.tourman.2007.05.005

Saxena, Gunjan \& Illbery, Brian, 2007, Integrated Rural Tourism: A Border Case Study, Annals of Tourism Research, Vol. 35 (1), 233-254, doi:10.1016/j.annals.2007.07.010

Wäsche, Hagen, 2015, Interorganizational cooperation in sport tourism: A social network analysis, Sport Management Review, 18 (4), 542-554, doi:10.1016/j.smr.2015.01.003

Waligo, V. M., Clarke, Jackie., dan Hawkins, Rebecca., 2013, Implementing Sustainable tourism: A Multi-Stakeholder Management Framework, Tourism Management, 36, 342-353, doi:10.1016/j.tourman.2012.10.008

Weidenfieled, Adi., 2013, Tourism and Cross Borders Regional Innovation System, Annals of Tourism Research, 42, 191-213, dx.doi.org/10.1016/j.annals.2013.01.003 